${ }^{14}$ Mühlbock, O., J. Nat. Cancer Inst., 12, 819 (1952).

${ }^{15}$ Lasfargues, E. Y., and Feldman, D. G., Cancer Res., 23, 191 (1963).

${ }^{16}$ Lasfargues, E. Y., and Murray, M. R., Acta Unio Intern. contra Cancrum (in the press).

${ }^{17}$ Dmochowski, L., Pearson, L. D., Grey, C. E., and Sykes, J. E., Eighth Intern. Cancer Congr., Moscow, 62 (1962).

${ }^{18}$ Blair, P. B., Meeting Rep. Mouse Tumor Virus by Bern, H. A., Science, 137, 351 (1962).

${ }^{10}$ Moore, D. H., Lasfargues, E. Y., Murray, M. R., Haagensen, C. D., and Pollard, E.' D., J. Biophys. Biochem. Cytol., 5, 85 (1959).

${ }^{20}$ Moore, D. H., Fed. Proc., 21, 942 (1962).

${ }^{21}$ Ardashnikov, S. N., and Spasskaia, I. G., J. Mikrobiol. Expidemiol. Immunol. (Mosk.), No. 9, 44 (1949). See also Moore, D. H., in Ciba Found. Symp. Tumor Viruses of Marine Origin (J. and A. Churehill, London, 1962).

${ }^{22}$ Bittner, J. J., Proc. Soc. Exp. Biol. Med., 59, 43 (1945).

${ }^{23}$ Dmochowski, L., Acta, 12, 583 (1956).

${ }^{24}$ Moore, D. H., and Lasfargues, E. Y., Fed. Proc., 21 (abs.), 460 (1962).

${ }^{25}$ Bittner, J. J., Science, 84, 162 (1936).

${ }^{26}$ Andervont, H. B., in Symp. Mammary Tumors in Mice (Publ. Amer. Assoc. Adv. Sci., No. 22, 128 (1945).

2: Deringer, Margaret K., J. Nat. Cancer Inst., 28, 203 (1962).

${ }^{28}$ Fekete, E., and Little, C. C., Cancer Res., 2, 525 (1942).

29 Andervont, H. B., and Dunn, T. B., J. Nat. Cancer Inst., 14, 317 (1953).

${ }^{30}$ Mühlbock, O., and Boot, L. M., Cancer Res., 19, 402 (1959).

${ }^{31}$ Bittner, J. J., and Cole, H. L., J. Nat. Cancer Inst., 27, 1273 (1961).

${ }^{32}$ Boot, L. M., Mühlbock, O., Röpcke, G., and Tengbergen, W., Cancer Res., 22, 713 (1962)

${ }^{33}$ Jesse, M. J., and Haagensen, C. D. (unpublished results).

${ }^{34}$ Bittner, J. J., Cancer Res., 1, 793 (1941).

${ }^{35}$ De Bruyn, W. M., and Benedetti, E. L., Proc. Eur. Reg. Conf. Electron Mieroscopy, Delft, 2, 999 (1960).
${ }^{36}$ Miroff, G., and Feldman, D. G. (unpublished results).

37 Bagg, H. J., Amer. J. Cancer, 27, 542 (1936).

${ }^{38}$ Bagg, H. J., and Jacksen, J., Amer. J. Cancer, 30, 539 (1937)

${ }^{30}$ Gardner, W. U., Cancer Res., 1, 345 (1941).

${ }^{40}$ Little, C. C., and Pearson, J., Amer. J. Cancer, 38, 224 (1940).

${ }^{1}$ Shimkin, M. B., in Symp. Mammary Tumors in Mice (Publ. Amer. Assoc. Adv. Sci., No. 22, 85, 1945)

42 Haagensen, C. D., and Randall, H. T., Arch. Path., 33, 411 (1942).

${ }^{48}$ Murray, W. S., and Little, C. C., Amer. J. Cancer, 37, 536 (1939).

${ }^{44}$ Heston, W. E., Mammary Tumors in Mice, 55 (see ref. 41).

${ }^{45}$ Yokoro, K., and Furth, J., J. Nat. Cancer Inst., 29, 887 (1962).

${ }^{6}$ Bryan, W. R., Calnan, D., and Moloney, J. E., J. Nat. Cancer Inst., 16, 317 (1955)

${ }^{47}$ De Thé, G., Heine, U., Ishiguro, H., Sommer, J. R., Beard, D., and Beard, J. W., Fed. Proc., 21, 919 (1962).

${ }_{48}$ Barnum, C. P., Ball, Z. B., Bittner, J. J., and Visseher, M. B., Science, 100, $575(1944)$

${ }^{49}$ Graff, S., Moore, D. H., Stanley, W. M., Randall, H. T., and Haagensen, C. D., Cancer, $2,755(1949)$.

${ }^{50}$ Burmester, B. R., Texas Symp. on Cancer Res., 15, 92 (1957).

${ }^{51}$ Zeigel, R. F., J. Nat. Cancer Inst., 26, 1011 (1961).

${ }^{52}$ Vogt, M., and Dulbecco, R., Virology, 16, 41 (1962).

${ }^{53}$ Eckert, E. A., Sharp, D. G., Beard, D., Green, I., and Beard, J. W., $J$ Nat. Cancer Inst., 16, 593 (1955).

${ }^{4}$ Lwoff, A., and Gutmann, A., Ann. Inst. Pasteur, 78, 711 (1950).

${ }^{65}$ Oberling, Ch., Berliner Symp. Fragen der Carcinogenese (Abhandl. Deut. Akad. Wiss. Berlin K1. Med. No. $3,177,1960$ ).

${ }^{56}$ Bern, H. A., Science, 131, 1039 (1960).

${ }_{57}$ Mühlbock, O., and van Jijssel, T. G., J. Nat. Cancer Inst., 15, 73 (1954).

${ }_{58}$ Braun, W Lampen. J. O Plescia, O. J and Pugh, J. Proc. Sixteenth Ann. Symp. Fundamental Cancer Res. (in the press).

${ }^{59}$ Lasfargues, E. Y., and Murray, M. R., Developmental Biology, 1, 413 (1959).

\title{
OBITUARIES
}

\section{Dr. H. J. Poole, C.B.E.}

Dr. Harold James Poole, who died suddenly on March 14 at the age of sixty-six, had a long and distinguished career in defence science and filled a number of important posts.

His studies were interrupted by the First World War and he obtained an external B.Sc. degree in chemistry at the University of London in 1919. His first contact with Government scientific work was during the War, when he served for a short time in the Research Department of the Royal Aircraft Establishment at Farnborough. This was followed by an appointment with Messrs. Curtis and Harvey, Ltd., with whom he gained useful experience in the manufacture of explosives at their Cliffe factory.

At the end of the War he took posts first in brewing and then in the oil industry. He returned to explosives, and to the Government service, in 1920, when he was appointed to the Inspection Branch at the Royal Naval Cordite Factory at Holton Heath. Here he started. research into the physical structure of cordite and other gels, a comparatively unexplored field. The work was continued when he was transferred in 1923 to the Research Department, Royal Arsenal, Woolwich, and enabled him to obtain a London Ph.D. (external) in 1926 and to publish papers in the Transactions of the Faraday Society. $\mathrm{He}$ continued to work on a variety of physico-chemical problems connected with propellants, and in collaboration with Dr. G. Rotter and the late Mr. W. J. Powell he developed the ' 100 per cent surveillance test for cordite'. The introduction of this test enabled a check to be maintained on the chemical stability of the cordite stored in magazines in Britain and overseas, and resulted in great financial savings in the replenishment of cordite stocks.

The Research Department at that time was administered by the War Office and was primarily concerned with research and development on explosives, ballistics and metallurgy on behalf of the three Services. It later became known as the Armament Research Department of the Ministry of Supply and is one of the parent units of the present Royal Armament Research and Development Establishment. Poole was associated with this organization throughout his working life and became one of its leading figures.
When the Research Department started to develop rockets in 1935, Dr. Poole became one of the pioneers in and construction of the 3-in. anti-aircraft rockets which this field, and he had a great deal to do with the design were tested in trials in Jamaica in 1938-39. A few months before the outbreak of the Second World War the Ministry of Supply set up a new organization-the Projectile Development Establishment-under Dr. (later Sir) Alwyn Crow to deal with the expanding field of military rockets. Poole's contributions to rocketry were varied and important, and included charge shapes of novel design-notably star-centred and cruciform charges which were used extensively in Britain and the United States; propellant compositions alternative to cordite (including the use of ammonium picrate); a special anti-aircraft fuze in which the pressure on the nose of the projectile was used to operate mechanical devices inside; methods of controlling the burning of rocket propellants and reducing the risks of eatastrophic pressure peaks. All these had a profound influence on the new technology.

In 1942 Poole was transferred to the division of the Director-General of Scientific Research (Ministry of Supply) as assistant director in charge of the Explosives Branch. In this post he co-ordinated the extra-mural work on explosives and he became intimately connected with the activities of the Scientific Advisory Council and its supporting committees which had been ereated to bring academic workers into the war effort. $\mathrm{He}$ became keenly interested in detonation phenomena and shaped charges, and devised successful methods for the control of the shape of the detonation wave front from highexplosive charges.

About a year later he returned once more to Woolwich, as assistant director in the Explosives Research Branch, but his stay there was short, for he was called on to go to Canada to play a leading part in the planning and construction of the Explosives Experimental Establishment at Valcartier, Quebec (now known as the Canadian Armament Research and Development Establishment). This was one of the happiest periods of his life and he revelled in the opportunities of introducing his own ideas into the design of buildings and plant. He became the first chief superintendent of the new organization. $\mathrm{He}_{\Theta}$ 
paid numerous visits to explosives research centres in the United States and built up a fund of goodwill out of his wide experience and the assistance he was able to give.

In 1945 Dr. Poole returned to England and rejoined the Armament Research Department, first as superintendent of explosives research and later as senior superintendent of chemical research. Much of the work for which he was responsible was in the process of being transferred to the Royal Gunpowder Factory at Waltham Abbey, which had been taken over as a centre for research and development into the chemistry of propellants, explosives and initiators. Dr. F. J. Wilkins was the first chief superintendent of this organization-now known as the Explosives Research and Development Establishment-and Dr. Poole succeeded him in 1946.

In 1949 he was appointed principal director of scientific research (defence) at Headquarters. It was not the kind of job he liked, being too remote from the laboratories, and he told his friends how glad he was "when they got fed up with him" and in 1950 gave hir, the important post of chief superintendent of armament research at Fort Halstead. He was created C.B.E. in the New Year Honours List of 1953 and was very proud the following November to organize a number of events-including a dinner in the Goldsmiths Hall-to celebrate the golden jubilee of his Establishment.

On the amalgamation of the Armament Research Establishment with the Armament Design Establishment in 1955, Poole became deputy to the director (Mr. Ewen M'Ewen) of the new organization, now known as the Royal Armament Research and Development Establishment. He was given the special responsibility of looking after the research programme. On reaching the age of sixty he remained to act as scientific adviser to the director and finally retired in December 1959.

Retirement was not allowed to sever Poole's activities in the armament field: he retained his interest by acting as a consultant to the Fighting Vehicles Research and Development Establishment and by serving on a number of committees of the War Office Scientific Advisory Council and the Ministry of Aviation Aeronautical Research Council.

Harold Poole was an extremely able and versatile scientist; although trained as a chemist he had a wide understanding of physies and engineering; he possessed considerable inventive capacity and was ever thinking of new things, the abundance of his ideas being sometimes an embarrassment to his colleagues. He was never really interested in administration but was always very approach able and willing to discuss personal problems with his staff. $\mathrm{H}_{\Theta}$ will be greatly missed, and our deep sympathy goes out to Mrs. Poole and her son, John, in their great loss.

W. B. LITTLER

\section{Dr. W. B. Haines}

Dr. Wirliam Burgess Haines, who died suddenly last March, joined the Soil Physics Department, Rothamsted Experimental Station, as one of its earliest members, in 1921. He was the first to show, by simple, but elegant, experiments that the moisture content in porous bodies like soil displays hysteresis: the value for any given equilibrium condition is not unique, but depends on whether it is approached by wetting or drying. Haines's treatment focused attention on the geometry of the pore space as essentially cellular, the larger voids being interconnected by necks of effectively smaller diameter; considerations of pressure deficiency under a meniscus, or suction values, showed that the equilibrium moisture content, for a given suction, was higher when water was being withdrawn than when it was being added.

This work, afterwards generalized by the late Dr. R. K. Schofield, who used thermodynamical considerations, lod to a clear understanding of water distribution and movement in soil, as affected by weather, cultivations, and vegetation.

In 1927, Haines left Rothamsted on appointment as head of the Soils Division of the Rubber Research Institute of Malaya. Some years later he joined the Dunlop Rubber Company of Malaya, to take charge of its extensive plantation experiments. He was held in a Japanese prisoner-of-war camp throughout the Second World War. On release, he returned to Harpenden and lived in retirement, except for a period of assistance to the Chemistry Department at Rothamsted in the statistical analysis and agronomical assessment of home and overseas manurial experiments. $\quad$ B. A. KEEN

\section{NEWS and VIEWS}

\section{Foreign Members of the Royal Society}

THE following have been elected foreign members of the Royal Society of London: Prof. E. Fauré-Fremiet, professor of comparative embryology, Collège de France, Paris, distinguished for his contributions to cell physiology and protozoology; Prof. K. J. Freudenberg, formerly professor of chemistry, University of Heidelberg, distinguished for his contributions to many branches of the chemistry of natural products; Prof. S. Wright, professor emeritus of geneties, University of Wisconsin, disting. uished for his contributions to quantitative genetics; Prof. H. Yukawa, director of the Research Institute for Fundamental Physics, Kyoto University, distinguished for his contributions to theoretical physics, particularly to the theory of elementary particles.

\section{The Royal Institute of Chemistry: Meldola Medal}

Dr. J. Trotrer has been awarded the Royal Institute of Chemistry's Meldola Medal for 1962 for his work in the field of chemical crystallography, with special reference to the structures of polynuclear aromatic compounds. Dr. J. Trotter was educated at St. Joseph's College, Dumfries, at St. Modan's High School, Stirling, and at the University of Glasgow. $\mathrm{He}$ obtained an honours degree in chemistry in 1954, and was awarded the Joseph
Black Medal, Muirhead Prize, and Mackay Smith Prize. He was appointed to an assistantship in the Chemistry Department, University of Glasgow, and began research under the direction of Prof. J. Monteath Robertson on crystal structure studies of organic molecules, particularly polynuclear aromatic hydrocarbons. In 1957 he completed his work for the Ph.D. degree, and until 1959 he worked as a National Research Council of Canada postdoctoral Fellow with Dr. W. H. Barnes at the laboratories of the Division of Pure Physics, Ottawa. Dr. Trotter returned in 1959, as an Imperial Chemical Industries Research Fellow, to Glasgow, where he continued the studies of hydrocarbon derivatives, and became engaged again in investigations of condensed ring hydrocarbons. In 1960 he was appointed to an assistant professorship in the Department of Chemistry, University of British Columbia, and has, with the encouragemont of Prof. C. A. McDowell, been organizing a erystallographic research group. Investigations have included the elucida. tion of the crystal and molecular structures of a variety of organic molecules, and a study of the stereochemistry of trivalent arsenic, in the course of which the structures of a number of derivatives have been determined.

The Meldola Medal, which is the gift of the Society of Maccabaeans, is normally awarded annually, the award for a particular year being made to the chemist who, 